\title{
IMPLEMENTASI PEMBELAJARAN DARING DALAM MENGEMBANGKAN KARAKTER TANGGUNG JAWAB PESERTA DIDIK PADA PEMBELAJARAN EKONOMI DI SMA KEMALA BHAYANGKARI 1 KUBU RAYA
}

\author{
Elsha Pertiwi, Sulistyarini, Okianna \\ Program Studi Pendidikan Ekonomi FKIP Untan Pontianak \\ Email:echapertiwi45@gmail.com
}

\begin{abstract}
This study aims to determine the implementation of online learning in developing the character of students' responsibility in economics subjects at SMAS Kemala Bhayangkari 1 Kubu Raya. The research method used is a qualitative research method with a descriptive approach. The source of the data for this research is the economics teacher of class XI IIS 1 and the data is the result of interviews with economics teachers and observation sheets and documentation. The results show that online learning planning in developing the character of student responsibility made by the teacher for learning in the form of lesson plans is very maximal and runs smoothly with a percentage of around 70\%-80\%, and a design for assessment is made, where the teacher plays a very important role in every learning implementation, and for the implementation is going well for now. So online learning can develop the character of students' responsibility in economic subjects at SMAS Kemala Bhayangkari 1 Kubu Raya.
\end{abstract}

\section{Keywords: Online Learning, Student Responsibilities}

\section{PENDAHULUAN}

Pendidikan adalah sarana yang paling penting untuk menjadikan sumber daya manusia yang lebih baik. Pendidikan membuat manusia memiliki pengetahuan dan ingin melakukan perubahan untuk perkembangan kualitas manusia di masa depan. Saat sekarang di Indonesia sedang maraknya virus yang tersebar di dunia yaitu virus covid 19 atau yang dikenal dengan virus corona. Virus corona sangat meresahkan masyarakat, karena berbahaya dan korbannya sangat banyak. Sudah lebih dari jutaan orang terinfeksi virus corona dengan penderita yang meninggal dunia berjumlah lebih dari ribuan orang. Virus corona ini sama sekali belum pernah terdeteksi dalam dunia medis. Virus ini merupakan virus yang menyebabkan infeksi saluran pernafasan, virus ini dapat menyebar melalui percikan air liur, dan bersentuhan. Dengan adanya wabah ini membuat para pemimpin negara untuk menerapkan kebijakan yang ketat dalam penyebaran. Salah atu yang dilakukan adalah social distancing, merupakan pilihan yang terbaik untuk mencegah penyebaran virus corona terutama bagi dunia pendidikan.

Social distancing adalah menjaga jarak sosial sebagai bentuk usaha untuk mengontrol penyebaran virus. Social distancing dapat dilakukan dalam beberapa bentuk mulai dari membatasi kontak tatap muka dan tangan, menghindari keramaian, dan melakukan kegiatan secara online baik untuk kegiatan pekerjaan maupun kegiatan pembelajaran. Untuk kegiatan pembelajaran pemerintah mengubah kegiatan pembelajaran di sekolah menjadi belajar dari rumah atau pembelajaran daring (dalam jaringan) agar peserta didik tetap belajar walaupun di rumah. Kemdikbud kemudian memperkuat dengan Surat Edaran Nomor 15 tahun 2020 tentang Pedoman Penyelenggaran Belajar dari Rumah dalam Masa Darurat Penyebaran Corona Virus Diseases (Covid19). 
Kegiatan pembelajaran dapat dilakukan dari rumah dilaksanakan secara daring / jarak jauh. Pembelajaran daring memang tidak mudah diterapkan baik bagi guru sebagai tenaga pendidik, anak-anak sebagai peserta didik maupun wali murid sebagai orang tua. Dengan pembelajaran daring peserta didik tidak bisa berinterkasi langsung dengan guru melainkan melalui bantuan teknologi dengan menggunakan berbagai macam aplikasi. Aplikasi yang dapat digunakan antara lain adalah whats app, google classroom, zoom, meet, dan lain sebagainya. Pembelajaran daring memang membuat peserta didik memiliki banyak tanggung jawab atas pelaksanaan dan pembuatan tugas sekolah.

Melalui pendidikan dapat dibentuk karakter seseorang yang akan menjadi pribadi yang cerdas, kreatif dan memiliki rasa tanggung jawab pada dirinya. Karakter merupakan perilaku yang membentuk nilai karakter dalam diri seseorang. Karakter seseorang dapat dilihat dari cara bertindak. Macam-macam karakter yaitu : religius, jujur, toleransi, disiplin, kerja keras, kreatif, mandiri, demokratis, rasa ingin tahu, dan tanggung jawab.

Tanggung jawab merupakan salah satu dari nilai karakter yang dimiliki seseorang. Tanggung jawab adalah tindakan yang dilakukan seseorang dalam menyelesaikan suatu pekerjaan yang sudah diambil. Seseorang harus bisa bertanggung jawab atas keputusan dan tindakan yang dilakukan. Tanggung jawab merupakan pendidikan moral dan budi pekerti yang sangat perlu ditanamkan pada setiap diri peserta didik agar peserta didik memiliki kepribadian yang baik. Tanggung jawab peserta didik di masa pandemi pada pembelajaran daring sangat membentuk adanya karakter tanggung jawab peserta didik saat mengikuti dan mengerjakan kewajibannya. Karakter tanggung jawab peserta didik adalah belajar, mengerjakan tugas, mengikuti arahan guru saat menjelaskan materi pembelajaran, mengikuti jam pembelajaran. Pembelajaran daring menjadi tantangan bagi seorang guru untuk membentuk karakter tanggung jawab. Hal tersebut dianggap penting dalam keadaan pandemi saat sekarang.

Mata pelajaran ekonomi merupakan mata pelajaran yang memiliki peranan penting dalam mengembangkan kemampuan pemahaman. Pada umumnya ekonomi dianggap sebagai mata pelajaran yang sulit dan membosankan apalagi untuk saat sekarang. Sebagai seorang pendidik khususnya guru harus bekerja keras terlebih dimasa pandemi agar peserta didik tetap mengikuti proses pembelajaran yang berlangsung.

Berdasarkan hasil pengamatan di SMA Kemala Bhayangkari 1 Kubu Raya, untuk saat sekarang sekolah melaksanakan pembelajaran daring (dalam jaringan). Pembelajaran daring baru di terapkan selama masa pandemi ini, pembelajaran daring membuat guru mata pelajaran ekonomi harus bekerja keras karena pelaksanaannya membutuhkan kreatif guru dalam membuat bahan ajar agar peserta didik tidak merasa bosan, dan mempunyai keinginan untuk ikut belajar. Serta dalam pembelajaran daring peserta didik juga dituntut untuk bertanggung jawab atas segala proses pembelajaran yang terjadi. Tanggung jawab peserta didik dalam pembelajaran daring adalah kehadiran tepat waktu, mengerjakan tugas, pengumpulan tugas tepat waktu. Penyebab sekolah SMA Kemala Bhayangkari 1 Kubu Raya melakukan pembelajaran daring adalah karena virus corona yang semakin menjadi-jadi.

Berdasarkan kondisi diatas peneliti tertarik untuk meneliti pembelajaran daring karena pada situasi saat ini pembelajaran daring dilaksanakan untuk mengantisipasi penularan kepada peserta didik. Dalam proses pembelajaran daring tanggung jawab peserta didik juga menjadi alasan peneliti untuk meneliti. Peneliti ingin melakukan penelitian dengan judul: "Implementasi Pembelajaran Daring Dalam Mengembangkan Karakter Tanggung Jawab Peserta Didik Pada Pembelajaran ekonomi di SMA Kemala Bhayangkari 1 Kubu Raya".

Berdasarkan latar belakang yang telah diuraikan di awal maka yang menjadi permasalahan dalam penelitian ini secara umum adalah "implementasi 
pembelajaran daring dalam mengembangkan karakter tanggung jawab peserta didik pada pembelajaran ekonomi di SMA Kemala Bhayangkari 1 Kubu Raya", dengan sub masalah:

(1)Bagaimana perencanaan pembelajaran daring dalam mengembangkan karakter tanggung jawab peserta didik pada pembelajaran ekonomi di SMA Kemala Bhayangkari 1 Kubu Raya?

(2)Bagaimana pelaksanaan pembelajaran daring dalam mengembangkan karakter tanggung jawab peserta didik pada pembelajaran ekonomi di SMA Kemala Bhayangkari 1 Kubu Raya? (3)Bagaimana mengevaluasi kegiatan pembelajaran daring dalam mengembangkan karakter tanggung jawab peserta didik pada pembelajaran ekonomi di SMA Kemala Bhayangkari 1 Kubu Raya? Adapun yang tujuan dalam penelitan ini untuk mengetahaui sebagai berikut: (1)Perencanaan pembelajaran daring dalam mengembangkan karakter tanggung jawab peserta didik pada pembelajaran ekonomi di SMA Kemala Bhayangkari 1 Kubu Raya.

(2)Pelaksanaan pembelajaran daring dalam mengembangkan karakter tanggung jawab peserta didik pada pembelajaran ekonomi di SMA Kemala Bhayangkari 1 Kubu Raya.

(3)Mengevaluasi kegiatan pembelajaran daring dalam mengembangkan karakter tanggung jawab peserta didik pada pembelajaran ekonomi di SMA Kemala Bhayangkari 1 Kubu Raya.

\section{METODE PENELITIAN}

Penelitian yang akan digunakan dalam pelaksanaan penelitian ini adalah penelitian kualitatif atau disebut juga penelitian naturalistic adalah pendekatan penelitian yang menjawab permasalahan penelitian memerlukan pemahaman secara mendalam dan menyeluruh mengenai objek yang diteliti. Menurut Sugiyono (2017, p,9) Metode penelitian kualitatif merupakan metode yang berlandaskan pada filsafat postpositivisme, yang digunakan dalam meneliti suatu kondisi obyek yang alamiah." Peneliti menggunakan pendekatan penelitian deskriptif berdasarkan pertimbangan bahwa masalah yang diteliti sedang berlangsung.
Hadari Nawawi (2012:67) "Metode penelitian deskriptif merupakan metode yang menggambarkan atu melukiskan serta menelaah kejadian yang sesuai dengan fakta dan dapat dijadikan kesimpulan dalam penelitian,"

Peneliti menggunakan pendekatan penelitian deskriptif dalam penelitian ini, karena peneliti bermaksud mendeksripsikan keadaan yang alami atau natural di SMA Kemala Bhayangkari $1 \mathrm{Kubu}$ Raya, dimana keadaan tersebut berhubungan dengan implementasi pembelajaran daring. Data yang ditemukan dipaparkan dengan berupa deskripsi. Setalah itu peneliti mewawancarai guru mata pelajaran ekonomi, serta melakuan observasi. Dari hasil observasi, wawancara dan dokumentasi yang telah dilakukan, data dianalisis untuk dapat dideskripsikan mengenai pembelajaran daring dalam membentuk karakter tanggung jawab. Peneliti menentukan metode yang akan digunakan dalam penelitian, karena dengan metode penelitian penulis dapat mengetahui tata cara untuk memecahkan masalah yang akan diteliti.

Tentunya bisa membantu peneliti untuk mengendalikan kegiatan serta mempermudah mengetahui kemajuan (proses) penelitian. Metode penelitian menggambarkan rancangan penelitian yang meliputi prosedur atau langkah-langkah yang harus ditempuh, waktu penelitian, sumber data serta dengan cara apa data tersebut diperoleh dan diolah.

Kehadiran peneliti di lapangan sangatlah penting dan diperlukan secara optimal. Peneliti sebagai instrumen sekaligus sebagai pengumpulan data. Peneliti juga bertindak sebagai pengamat partisipan dan kehadiran peneliti perlu diketahui statusnya oleh informan.

Tempat penelitian adalah tempat yang digunakan untuk memperoleh informasi serta pemecahan masalah penelitian berlangsung. Penelitian ini berlokasi di SMA Kemala

Bhayangkari 1 Kubu Raya, tepatnya di Jalan Adisucipto, Sungai Raya, Kec. Sungai Raya, Kubu Raya. Sumber data adalah subjek atau objek dari mana asal data dalam penelitian itu diperoleh. Menurut Herdiansyah (2013:8), "Data adalah suatu atribut yang melekat pada suatu objek tertentu, berfungsi sebagai informasi yang dapat di pertanggung jawabkan, dan diperoleh melalui suatu metode instrument pengumpulan data". Sumber data dibagi menjadi sumber data primer dan sumber data sekunder. Sumber data dalam penelitian ini diperoleh dari sumber data primer dan sumber data 
sekunder yang bersifat kualitatif yaitu sebagai berikut: (1) Sumber Data Primer Menurut Sugiyono (2017:308), "Data Primer adalah sumber data yang langsung memberikan data kepada pengumpul data". Sumber data primer diperoleh dengan cara melakukan wawancara langsung antara peneliti dengan informan yang di anggap paling penting dalam mengetahui secara rinci dan secara jelas mengenai fokus penelitian. Informasi tersebut adalah guru ekonomi kelas XI IIS 1 SMA Kemala Bhayankari 1 Kubu Raya. (2) Sumber Data Skunder

Menurut Sugiyono

(2017:309), "Data sekunder adalah sumber data yang tidak langsung memberikan data kepada pengumpul data". Sumber data sekunder diperoleh misalnya melalui orang lain atau dokumentasi. Data sekunder adalah data yang berbentuk fisik seperti catatan, dokumensi, dan lain-lain. Dalam penelitian ini yang menjadi data sekunder adalah kegiatan kerja peserta didik, dan foto saat proses wawancara bersama informan di SMA Kemala Bhayangkari 1 Kubu Raya.

Prosedur pengumpulan data dalam penelitan ini adalah Menurut Umar (2014 :49), "Di dalam penelitian ilmiah, ada beberapa teknik pengumpulan data, yaitu angket (kuesioner), wawancara, observasi, dan tes". Menurut Herdiansyah (2013:15), "Dalam penelitian kualitatif, dikenal beberapa metode pengumpulan data yang umum digunakan. Beberapa metode tersebut antara lain adalah wawancara, observasi, dan studi dokumentasi". Prosedur pengumpulan data dalam penelitian ini menggunakan teknik wawancara, dan dokumentasi sebagai berikut:

(1)Wawancara adalah kegiatan untuk mendapatkan informasi dimana sang pewawancara melontarkan pertanyaanpertanyaan untuk dijawab oleh orang yang di wawancarai. Menurut Esterberg dalam Sugiyono (2017:231), "Definisi ini menjelaskan bahwa wawancara adalah pertemuan dua orang untuk bertukar informasi dan ide melalui tanya jawab, sehingga dapat dikonstruksikan makna dalam suatu topik tertentu". Peneliti menggunakan teknik wawancara untuk memperoleh data dan informasi tentang pembelajaran daring terhadap karakter tanggung jawab dari guru kelas XI IIS 1 SMA Kemala Bhayangkari 1 Kubu Raya. Kegiatan wawancara ditujukan kepada Guru SMA Kemala Bhayangkari 1

Kubu Raya. Pertanyaan disusun berdasarkan fokus dan rumusan masalah. Peneliti menggunakan teknik wawancara untuk mendapatkan data yang valid dari informan.

(2)Dokumentasi dalam penelitian ini, peneliti menggunakan dokumen berupa aktivitas belajar dan hasil belajar yang terdapat pada guru mata pelajaran ekonomi. Menurut Nawawi (2015:101), “Teknik ini adalah cara mengumpulkan data yang dilakukan dengan kategorisasi dan klasifikasi bahan-bahan tertulis yang berhubungan dengan masalah penelitian, baik dari sumber dokumen maupun buktibukti koran, majalah dan lainlain".

Pada penelitian ini peneliti telah melakukan studi dokumenter. Dokumenter tersebut berupa foto saat melakukan penelitian, atau screenshoot dari berbagai aplikasi yang digunakan. (3)Observasi Hadari Nawawi (2015:100), teknik observasi langsung adalah cara pengumpulan data yang dilakukan melalui pengamatan dan pencatatan gejalagejala yang tampak pada objek penelitian yang pelaksanaannya langsung pada tempat dimana suatu peristiwa, keadaan atau situasi terjadi."

Metode ini digunakan untuk mengetahui situasi dan kondisi serta mengamati objek secara langsung untuk memperoleh data akurat.

Objek dalam penelitian ini adalah peserta didik kelas XI IIS SMA Kemala Bhayangkri 1 Kubu Raya. Metode ini dilaksanakan secara daring, dikarenakan situasi sekarang tidak diperbolehkan untuk melakukan pembelajaran secara tatap muka maka untuk melakukannya peneliti menggunakan aplikasi zoom meeting, google classroom, dan whats app. (a) Whats App adalah aplikasi pesan untuk ponsel cerdas. Dengan menggunakan WhatsApp, peneliti dapat melihat kegiatan yang guru lakukan selama proses pembelajaran. Guru melakukan komunikasi kepada peserta didik, berbagi file yang akan dipelajarai, bertukar foto video untuk proses pembelajaran. Dan melalui whats app dapat digunakan untuk absen kehadiran peserta didik serta pengumpulan tugastugas. (b) ZoomMeeting adalah sebuah perusahaan teknologi komunikasi, Perusahaan ini menyediakan layanan perangkat videotelefoni dan obrolan daring berbasis P2P komputasi awan yang digunakan untuk telekonferensi, bekerja jarak jauh, belajar jarak jauh, 
dan berhubungan sosial. Dengan aplikasi zoom ini guru mengadakan pertemuan dan melaksanakan kegiatan pembelajaran, seperti guru menjelaskan materi yang akan disampaiakan dan peserta didik juga dapat berinteraksi secara langsung meski dengan jarak jauh.

Analisis Data yang digunakan dalam penelitian ini adalah Menurut Gunawan (2016:209), "Analisis data adalah sebuah kegiatan untuk mengatur, mengurutkan, mengelompokkan, memberi kode/tanda, dan mengkategorikannya sehingga diperoleh suatu temuan berdasarkan fokus atau masalah yang ingin dijawab". Analisis data dalam penelitian ini mengacu pada analisis kualitatif yang dinyatakan oleh Miles \& Huberman. Menurut Sugiyono (2017:247),

"Mereduksi data adalah kegiatan merangkum, memilih hal-hal pokok, memfokuskan pada hal-hal yang penting, dan mencari tema dan polanya". Reduksi data merupakan proses berfikir sensitif yang memerlukan kecerdasan, keluasan, dan kedalaman wawancara yang tinggi. Data yang diperoleh di lapangan jumlahnya lumayan banyak, sehingga perlu dicatat secara teliti dan rinci. Peneliti memilih data yang relevan, penting dan bermakna, dan data yang tidak berguna, untuk menjelaskan apa yang menjadi sasaran analisis. Lalu menyederhanakannya dengan membuat fokus, klarifikasi, dan abstraksi data.

Pada tahap reduksi data, peneliti mengumpulkan semua data yang dibutuhkan yaitu mengenai perencanaan pemberian remedial oleh guru, dan menemukan kesulitan yang dihadapi guru dalam melaksanakan remedial. Untuk itu peneliti memilih, mengelompokkan jenis data yang ditemukan selama proses penelitian berlangsung dan difokuskan sesuai dengan rumusan masalah yang telah dirumuskan.

2.Tahap Penyajian Data (Data Display) Setelah data direduksi, maka langkah selanjutnya adalah melakukan penyajian data. Menurut Miles \& Huberman (dalam gunawan 2016:211), "Pemaparan data sebagai sekumpul informasi tersusun, dan memberi kemungkinan adanya penarikan kesimpulan dan pengambilan tindakan". Dalam penelitian kualitatif menyajikan data dengan teks yang bersifat naratif. Penyajian data tersebut akan menghasilkan teori grounded, yaitu teori yang ditemukan di lapangan dan selanjutnya di uji melalui pengumpulan data yang terus menerus.

3.Tahap Penarikan Kesimpulan dan Verifikasi (Conclusion Drawing/Verifying) Menurut Gunawan (2016:212), "Penarikan kesimpulan merupakan hasil penelitian yang menjawab focus penelitian berdasarkan hasil analis data. Simpulan disajikan dalam bentuk deskriptif objek penelitian dengan berpedoman pada kajian penelitian". Sedangkan menurut Herdiansyah (2013:350), "Penarikan kesimpulan merupakan tahapan terakhir dari analisis data dimana kesimpulan yang akan diperoleh berasal dari irisan dan benang merah di tahap display data yang akan menjawab tujuan penelitian dan pertanyaan penelitian".

Berdasarkan para pendapat di atas dapat disimpulkan bahwa pada tahap penarikan kesimpulan dan verifikasi adalah hasil suatu proses analisis data yang bertujuan menjawab pertanyaan atau fokus penelitian.

Teknik Pemeriksaan Keabsahan Data dalam penelitan ini adalah Uji keabsahan data dalam penelitian, sering hanya ditekankan pada uji validitas dan reliabilitas. Menurut Sugiyono (2017:268), "Dalam penelitian kuantitatif, untuk mendapatkan data yang valid dan reliabel yang di uji validitas dan rehabilitasnya adalah instrumen penelitiannya, sedangkan dalam penelitian kualitatif yang di uji adalah datanya". Oleh karena itu menurut Susan Stainback dalam Sugiyono (2017:268) menyatakan bahwa, "Penelitian kuantitaif lebih menekankan pada aspek validitas". Untuk meningkatkan kemampuan peneliti dalam menilai keakuratan hasil penelitian serta untuk meyakinkan pembaca akan akurasi maka diperlukan strategi validitas. Menurut Creswell (2017:269-271) terdapat 8 strategi validitas, yaitu

"Triangulasi, member checking, deskripsi yang kaya dan padat, klarifikasi bias, informasi "yang berbeda" atau "negatif", waktu lama dilapangan, tanya jawab rekan peneliti, auditor". Jadi dalam penelitian ini peneliti akan menggunakan strategi triangulasi. Triangulasi adalah salah satu strategi dimana "Mentriangulasi sumber data informan yang berbeda dengan memeriksa bukti-bukti yang berasal dari sumber tersebut dan menggunakannya untuk membangun justifikasi tema-tema secara koheren" (Cresswell, 2017:269). Maka, untuk meningkatkan keakuratan digunakan strategi triangulasi dimana informasi yang diperoleh dari hasil wawancara akan 
dikoreasikan dengan bukti-bukti dokumen yang ada. Dalam penelitian ini peneliti melakukan wawancara, observasi, dan dokumentasi. Peneliti mewawancarai guru mata pelajaran ekonomi, dengan melakukan tanya jawab yang berhubungan dengan penelitian. Setelah itu, peneliti melakukan kegiatan observasi yang dilihat pada saat proses absensi yang terjadi melalui aplikasi whatss app, pemberian materi, setelah itu guru melakukan kegiatan pembelajaran menggunakan aplikasi zoom yang diikuti peserta didik. kemudian peneliti juga melihat cara guru untuk mengevaluasi kegiatan tersebut dengan melihat peserta didik mengumpulkan tugas harian yang diberikan setelah guru memberikan penjelasan materi yang bersangkutan. Pengumpulan tugas perminggu juga menunjukkan tanggung jawab peserta didik dalam menyelesaikan tugas. Sedangkan untuk kegiatan dokumentasi, peneliti melakukannya dengan memfoto sebagai bukti adanya peserta didik yang mengumpulkan tugas perminggu, untuk pengumpulan tugas setiap pembelajaran peneliti menscreenshoot tugas yang peserta didik kumpulkan melalui aplikasi whats app, sedangkan untuk absensi kehadiran peneliti juga melakakukan screenshoot sebagai bukti kehadiran peserta didik.

\section{HASIL DAN PEMBAHASAN Hasil}

Penelitian dilakukan di SMAS Kemala Bhayangkari 1 Kubu Raya. Dengan melibatkan satu kelas yaitu XI IIS 1. Jumlah peserta didik yang menjadi subjek penelitian adalah 29 orang. Kelas tersebut diberi perlakuan model pembelajaran dalam jaringan (daring). Proses pembelajaran dilakukan oleh Ibu Dwi Puji Lestari selaku guru mata pelajaran ekonomi di SMAS Kemala Bhayangkari 1 Kubu Raya dan yang menjadi observer adalah Elsha Pertiwi selaku peneliti. Observer dalam penelitian ini bertugas untuk mengamati Proses Pembelajaran yang dilakukan oleh guru dan mengamati tanggung jawab peserta didik pada kelas XI IIS 1. Penelitian dilakukan sebanyak satu kali pertemuan pada kelas XI IIS 1 di SMAS Kemala Bhayangkari 1 Kubu Raya. Adapun rincian hasil penelitian yang telah dilakukan peneliti dikelompokkan berdasarkan sub masalah yang terdapat dalam penelitian ini adalah sebagai berikut: (a.) Tahap Persiapan ini dilakukan peneliti dengan berdiskusi bersama guru mata pelajaran ekonomi kelas X1 IIS 1. Adapun persiapan yang dilakukan adalah: (1) Membuat perangkat pembelajaran, yaitu berupa Rencana Pelaksanaan Pembelajaran (RPP) menggunakan model pembelajaran dalam jaringan (daring) untuk kelas XI IIS 1 berdasarkan silabus kurikulum 2013. (2)Membuat instrument penelitian berupa lembar observasi karakter tanggung jawab dan lembar observasi proses pembelajaran untuk pengamatan saat proses pembelajaran berlangsung. (b) Tahap Pelaksanaan yaitu melaksanakan kegiatan wawancara, observasi dan dokumentasi.

(1) Wawancaran Peneliti mewawancarai guru mata pelajaran ekonomi di SMA Kemala Bhayangkari 1 Kubu Raya, di luar jam pelajaran dengan kisi-kisi yang telah ditentukan. (2) Observasi Peneliti melakukan kegiatan observasi yang dilakukan disekolah dengan melihat terjadinya proses pembelajaran secara daring dari mulai kegiatan hingga akhir.

(3) Dokumentasi Peneliti melakukan dokumentasi dengan memfoto setiap kegiatan yang terjadi pada saat pembelajaran berlangsung.

(c)Tahap Evaluasi Merupakan tahap dimana guru mengumpulkan berbagai catatan dan tugas yang telah dikerjakan oleh peserta didik untuk dinilai. 3 . Hasil Observasi Sesuai dengan metode pengumpulan data, peneliti melakukan observasi yang berpedoman pada lembar observasi. Data observasi yang peneliti peroleh didapat dari pengamatan yang dilakukan oleh peneliti terhadap pelaksanaan pembelajaran daring di SMAS Kemala Bhayangkari 1 Kubu Raya. Observasi dilakukan sebanyak 1 (satu) kali yang dilaksanakan pada tanggal 23 Agustus 2021.

Berdasarkan observasi yang dilakukan, peneliti mengamati bagaimana kesiapan guru dalam merancang pembelajaran yang akan berlangsung selama masa pandemic. Pembelajaran berlangsung tidak dengan tatap muka melainkan berlangsung dengan jarak jauh / dalam jaringan (daring). Saat peneliti melakukan wawancara dengan guru mata pelajaran ekonomi, guru mengatakan bahwa saat wabah terjadi di Kalimantan Barat ini pembelajaran di sekolah terjadi tidak dengan tatap muka melainkan melalui jarak jauh / dalam jaringan (daring), setelah itu peneliti melakukan observasi dengan cara mengamati proses terjadinya kegiatan pembelajaran 
yang berlangsung. Guru juga melihatkan rancangan pembelajaran yang beliau rancang sementara untuk kegiatan pembelajaran pada masa pandemic. Rancangan yang dibuat tentunya berbeda dengan rancangan pembelajaran tatap muka. Pada saat terjadinya proses aktivitas belajar, peneliti ikut mengamati proses aktivitas belajar berlangsung dari awal guru mengabsen peserta didik, memberikan penjelasan materi, hingga pemberian tugas dan tak lupa guru juga menjelaskan sistem pengumpulan tugas yang harus mereka dengarkan.

Untuk mengabsen peserta didik guru menggunakan aplikasi whats app dengan cara membuat grup dan disitulah peserta didik harus merespon chat yang diberikan guru, dengan batas waktu 5 menit. Absensi kehadiran peserta didik untuk di kelas XI IIS 1 sebanyak 25 peserta didik sama dengan 86,2 yang hadir dan dapat dikatagorikan dalam golongan (A). Setelah itu guru memulai pembelajaran dengan menggunakan aplikasi zoom meeting untuk menjelaskan materi . Pembelajaran selama masa pandemic memiliki waktu yang lebih sebentar dibandingkan dengan pembelajaran tatap muka, pembelajaran daring 1mata pelajaran 30menit.

Menurut pengamatan peneliti guru memberikan penjelasan tentang materi pembelajaran dengan sangat jelas, bahkan guru juga bertanya kepada peserta didik apakah sudah mengerti atau belum . Didalam pelaksanaan pembelajaran jarak jauh / pembelajaran dalam jaringan (daring) terjadi sangat baik komunikasi berjalan hanya saja memiliki beberapa kendala dengan sinyal / jaringan. Setelah itu guru memberikan tugas untuk dikerjakan oleh masing-masing peserta didik. Untuk pengumpulan tugas guru memiliki dua cara yaitu pertama dengan menggunakan whats app karena disana peserta didik diberi batas waktu pengumpulan, dan yang mengerjakan tugas melalui aplikasi whats app hanya 23 peserta didik sama dengan 79,3 yang mengerjakan dan dapat dikatagorikan (B) dan setiap hari senin peserta didik wajib mengumpulkan langsung ke meja guru tugas yg telah mereka kerjakan sebanyak 22 peserta didik sama dengan 75,8 yang mengumpulkan dan dapat dikatagorikan (B) dan pengambilan buku yang telah mereka kumpulkan dilakukan pada hari kamis. Tentunya dengan menggunakan protocol yang benar.

Ini semua merupakan cara guru mengevaluasi kegiatan pembelajaran daring yang berlangsung selama proses pembelajaran. Peneliti melihat adanya rancangan penilaian yang dibuat guru, penilaian dapat dilihat dari kehadiran peserta didik setiap pembelajaran khususnya mata pelajaran ekonomi. Setelah itu guru juga melihat keaktifan pada saat pembelajaran berlangsung dan rasa tanggung jawab yang dimiliki setiap peserta didik, dengan cara absensi sebagai peserta didik. Hasil Wawancara Berdasarkan lembar pertanyaan yang dibuat oleh peneliti, dengan 1 (satu) responden. Deskripsi hasil wawancara pada guru mata pelajaran ekonomi mengenai pembelajaran daring dalam mengembangkan karakter tanggung jawab peserta didik disajikan berdasarkan indikator pembelajaran daring dan karakter tanggung jawab. Berikut hasil wawancara kepada guru mata pelajaran ekonomi. (1) Terkait dengan pertanyaan pertama yang diajukan kepada guru, bagaimana rancangan program yang ibu buat untuk peserta didik dalam mengembangkan karakter tanggung jawab peserta didik pada mata pelajaran ekonomi. Selama ini kebiasaan kami untuk menerapkan pembelajaran kepada peserta didik selalu dimulai dengan pembuatan RPP. Dimana didalam RPP itu kita cantumkan untuk alokasi yang memang harus mereka penuhi. RPP untuk sekarang atau pada masa pandemi ini memiliki alokasi waktu 1 jam pelajaran itu 30menit.

Didalam RPP tercantum aktifitas yang akan terjadi misalnya begini , pada hari itu rancangan RPP ingin menyampaikan materi tertentu, setelah penyampaian materi kemudian di dalamnya akan ada penugasan, nah itu juga kita cantumkan tugas yang mereka kumpulkan itu akan di akhiri sampai pukul berapa? Nah dari situ kita juga akan meningkatkan rasa tanggung jawab mereka terhadap kewajiban yang harus mereka selesaikan sebagai seorang pelajar. Masa pandemi ini peserta didik tetap harus melaksanakan pembelajaran walaupun tanpa bimbingan seorang guru secara tatap muka. Dari situ nanti kita bisa menilai bahwa peserta didik itu memiliki rasa tanggung jawab atau tidak dalam pembelajaran.

(2) Terkait dengan pertanyaan kedua yang diajukan kepada guru, bagaimana respon peserta didik selama kegiatan pembelajaran ekonomi berlangsung, Untuk responnya Alhamdulillah selama ini walaupun kita 
belajar secara daring atau online itu kalau kita ukur persentasinya sekitar $70 \%$ atau $80 \%$ itu mereka mempunyai respon baik Karena walaupun pembelajaran online/daring tetap mereka kita pantau melalaui aplikaiaplikasi yang dapat digunakan. Dengan catatan ada penekanan penekanan tertentu sebelum kita memulai proses kegiatan pembelajaran misalnya kita akan memulai pembelajaran pukul 8 , nah sebelum pukul 8 itu kita sudah memberikan peringatan di whats app grupnya bahwa kita sebentar lagi akan memulai proses kegiatan pembelajaran ekonomi kemudian kita juga menentukan kriteria penggunaan absensi, misalnya hari ini kita menggunakan absensi di whats app grup, kemudian di pertemuan berikutnya kita menggunakan absensi di Google Classroom ,atau dengan mengunakan pesan suara seperti itu agar mereka selalu memantau apa yang diinginkan oleh kita dan mereka juga bisa memenuhi dari keinginan gurunya.

(3)Terkait dengan pertanyaan ketiga yang diajukan kepada guru untuk pembelajaran langkah-langkah apa saja yang ibu berikan kepada peserta didik, yang kita lakukan semuanya sudah tercantum dalam RPP. Ada tiga kegiatan, yang pertama dimulai dari pembukaan, jadi awal kita masuk di kelas tersebut kita akan selalu mengingatkan peserta didik melalui whatsapp grup nah disitu kita buka dengan salam kemudian kita juga meminta peserta didik untuk selalu sebelum memulai pelajaran dengan berdoa menurut agama dan keyakinan mereka msing-masing. Kemudian kita melakukan absen, absennya dapat melalui whats app grup, atau bisa menggunakan pesan suara, respon mereka terhadap salam kita. Kemudian dalam RPP tersebut juga dicantumkan kegiatan inti, didalam kegiatan inti itu kita akan menyampaikan materi yang akan kita bahas di pertemuan pada saat ini, dikegiatan inti tersebut juga diberikan langkah-langkah sampai dengan penugasan yang diberikan guru. kemudian terakhir penutup kita mengingatkan kembali, menyimpulkan berkaitan dengan materi yang sudah kita bahas kemudian mengingatkan kembali bahwa tugas yang diberikan kepada peserta didik itu paling lambat harus dikumpulkan pukul berapa dengan menggunakan apa.
(4)Terkait dengan pertanyaan keempat yang diajukan kepada guru apakah terdapat kendala dalam melaksanakan aktivitas belajar jarak jauh/ dalam jaringan (daring), Tentunya kalau kendala untuk belajar secar online / daring pasti ada. Mungkin tidak hanya saya sebagai guru mata pelajaran ekonomi tapi juga guru-guru lain juga memiliki kendala. Terutama untuk jaringan / sinyal tetapi kebiasan dari peserta didik ketika mereka mempunyai kendala dijaringan / sinyal dimana yang namanya kita belajar online/ daring kesuksesan pembelajaran itu juga tergantung pada sinyal. Sebelum atau pun sesudahnya mereka selalu konfirmasi dengan gurunya dengan meminta maaf misalnya pada pembelajaran ekonomi karena ada gangguan jaringan. Kemudian masih bersamaan dengan jaringan pada saat proses pembelajaran apabila kita menggunakan aplikasi zoom kalau jaringan tidak bagus tentunhya suara yg di terima peserta didik tentunya juga mengalami kendala, misalnya suara yang mereka dengar itu terputus-putus atau kita sebagai gurunya juga merasa ketika mereka merespon suaranya tidak maksimal. Video yang kita buat juga untuk materinya juga tidak bisa mereka lihat Karena tidak maksimalnya jaringan. Kedua mereka sulit untuk fokus dalam artian mereka tidak fokus karena beberapa faktor, yang pertama karena tidak dipantau secara langsung dan banyaknya gangguan dari rumah. Ketiga yaitu handphone yang kurang memadai disaat baru-baru kegiatan pembelajaran banyak peserta didik yang mengeluh dengan ketidak mampuan handphone dalam mendownload aplikasi yang akan digunakan. (5)Terkait dengan pertanyaan kelima yang diajukan kepada guru mengenai penilaian afektif seperti apa yang diberikan ibu kepada peserta didik selama pembelajaran daring, untuk penilaian afektif atau sikap yang kita berikan kepada peserta didik itu yang pertama kita melihatnya dari respon mereka ketika awal pembelajaran. Guru menyapa sebelum pembelajaran dimulai kita dapat melihat mereka cepat atau tidak memberikan respon atau menjawab salam dari guru.Selama proses pembeajaran kalau kita menggunakan aplikasi zoom kita dengan mudah memantau mereka yg pertama dari kesiapan mereka saat akan dimulai pembelajaran, kemudian respon mereka saat guru menjelasakan materi pembelajaran apakah mereka menyimak atau sedang bermain, atau dari gaya duduk mereka, apakah santay atau sambil baring, seragam yang dikenakan apakah sesuai dengan yang mereka kenakan pada hari itu. kita bisa 
menjadikan pedoman sebagai penilaian afektif atau sikap mereka. Kemudian juga bisa melihat ketepatan waktu pengumpulan tugas denga cara daring dan luring dengan masing-masing memiliki batasan waktu. (6) Terkait pertanyaan keenam yang diajukan kepada guru mengenai pembelajaran jarak jauh / dalam jaringan (daring) berlangsung apakah peserta didik hadir tepat waktu, untuk ketepatan waktu kehadiran mereka di mata pelajaran ekonomi itu tidak semuanya bisa hadir tepat waktu, ada yang terlambat artinya apa untuk yg berada di daerah yang berkaitan dengan kendala sinyal tentunya mereka mengalami kendala jaringan masuknya juga terlambat, tapi sudah semaksimal mungkin diingatkan kembali sebelum memulai pembelajaran sebentar lagi kita masuk di mata pelajaran ekonomi, mereka sudah mempunyai rambu bahwa akan dimulai pembelajaran ekonomi. kita juga memberikan batasan waktu untuk kehadiran / absen, dengan alokasi sekitar lima menit dari jam pelajaran dimulai.

\section{Pembahasan}

Berdasarkan penelitian yang dilaksanakan di SMA Kemala Bhayangkari 1 Kubu Raya, peneliti melihat dan mengamati bagaimana implementasi pembelajaran daring untuk mengembangkan karakter tanggung jawab peserta didik. Sesuai dengan fokus yang dibuat maka peneliti akan menjabarkan permasalahan berdasarkan hasil wawancara dan observasi yang telah dilaksanakan. 1 . Perencanaan pembelajaran daring dalam mengembangkan karakter tanggung jawab peserta didik Berdasarkan hasil wawancara dan observasi maka sub masalah pertama dalam penelitian ini dapat terjawab yaitu perencanaan pembelajaran daring pada mata pelajaran ekonomi di SMAS Kemala Bhayangkari 1 Kubu Raya, yaitu dengan membuat perencanaan yang baik karena tanpa perencanaan kegiatan tidak akan berjalan dengan lancar. Menurut Majid (2011:17) perencanaan dapat diartikan sebagai proses penyusunan bahan ajar, menggunakan media, menggunakan pendekatan dan metode pembelajaran, serta mengevaluasi dalam kurun waktu tertentu untuk mencapai tujuan pembelajaran yang telah ditetapkan.
Perencanaan pembelajaran dimulai dengan rancangan proses pembelajaran (RPP).

Dimana didalm RPP dicantumkan kegiatan apa saja yang akan dilaksanakan untuk proses pembelajaran, dengan pembagian waktu yang pas untuk setiap kali pertemuan. Satu kali pertemuan beralokasi tiga puluh menit pada setiap pertemuan dimasa pandemi saat sekarang. Pelajaran ekonomi satu kali pertemuan yaitu memiliki dua jam pelajaran yang artinya biasanya memiliki waktu Sembilan puluh menit sekarang hanya enam puluh menit. Dari waktu tersebut rancangan RPP harus mencakup kegiatan pembuka, inti, dan penutup. Rancangan pembelajaran juga dilengkapi dengan sistem penilaian untuk melihat apakah peserta didik memiliki rasa tanggung jawab atas pelajaran atau tidak. Respon peserta didik untuk kegiatan pembelajaran secara daring sekarang sangat baik berbeda dengan dahulu, dulu waktu awal pembelajaran itu persentase nya sangat rendah sedangkan sekarang sudah bagus sekitar 70\%-80\%. Karena sekarang mereka mulai aktif dan sudah mulai terbiasa akan kegiatan pembelajaran secara online, dan banyak faktor yang sudah menunjang baik dari segi jaringan / sinyal yang mereka dapatkan secara gratis dari pemerintah, handphone yang sudah lumayan membaik dari orang tua dan rasa tanggung jawab peserta didik atas pelajaran.

Langkah-langkah pembelajaran secara daring sudah tercantum di rancangan prosesm pembelajaran yang terdapat kegiatan pembukaan, kegiatan inti, dan kegiatan penutup, dan juga terdapat rancangan penilaian yang dibuat guru untuk menilai dari peserta didik dari proses pembelajaran, dimana yang dilihat guru dalam kegiatan pembuka yaitu respon menjawab salam dari guru, keinginan belajar, dan kehadiran dalam kegiatan pembelajaran. Sedangkan pada kegiatan inti keseriusan menyimak penjelasan guru, kesiapan dalam pembelajaran, gaya belajar dan seragam yang dipakai saat proses pembelajaran dan tanggung jawab atas tugas yang diberikan. Pada kegiatan penutup yang dapat dinilai yaitu hasil pembelajaran yang didapat dari pembelajaran, pengumpulan tugas yang menjadi tanggung jawab peserta didik.

Hasil penelitian sebelumnya yang dilakukan oleh Dewi Fatimah yang berjudul analisis pelaksanaan pembelajaran daring pada masa pandemi covid-19 di sekolah dasar. Hasil penelitian menggambarkan pelaksanaan pembelajaran daring sudah cukup baik peserta didik dan guru telah 
memiliki fasilitas-fasilitas dasar yang dibutuhkan, hal itu menggambarkan kesiapan pelaksanaan pembelajaran daring. Dalam pelaksanaan pembelajaran daring guru sudah melakukan perencanaan pembelajaran dan sudah melaksanakan pembelajaran dengan baik yaitu menggunakan media pembelajaran, strategi, metode dan pendekatan pembelajaran yang disesuaikan dengan peserta didik.

2.Pelaksanaan pembelajran daring dalam mengembangkan karakter tanggung jawab peserta didik berdasarkan hasil wawancara dan observasi maka sub masalah kedua dalam peneitian ini dapat

terjawab yaitu pelaksanaan pembelajaran daring pada mata pelajaran ekonomi di SMAS Kemala Bhayangkari 1 Kubu Raya.

Pelaksanaan pembelajaran daring terlaksana menggunakan pedoman dari rancangan program pembelajaran yang dibuat guru yang akan dilaksanakan. Menurut Widyastuti (2021:23) menyatakan bahwa

"sistem pembelajaran daring (dalam jaringan) merupakan sistem pembelajaran tanpa tatap muka secara langsung antara guru dan siswa tetapi dilakukan melalui online yang menggunakan jaringan internet”. Pelaksanaan pembelajaran daring dimulai dengan pertama pembukaan dengan guru mengucapkan salam dan dapat meihat sikap peserta didik yang merespon salam guru tersebut, setelah itu guru mulai memberikan arahan untuk proses mengabsen, proses mengabsen guru kadang berubah adakalanya guru meminta respon peserta didik dengan menggunakan meneruskan chat yang sudah disediakan melalui whats app, atau guru meminta respon dari murid untuk mengabsen dirinya melalui suara / pesan suara yang dikirim melalui whats app grup dan ada kalanya guru mengabsen menggunakan zoom meeting langsung.

Semua akan ada arahan dari guru dengan tujuan agar peserta didik lebih memiliki rasa tanggung jawab karena absensi dilakukan berbeda. Kemudian setelah itu guru memperhatikan dari kesiapan mengikuti pelajaran, posisi saat zoom meeting apakah duduk dengan rapi, atau sedang berbaring, dan kerapian dan kesesuaian dalam berpakaian. Sedangkan pada kegiatan inti guru memulai kegiatan pembelajaran dengan cara menjelaskan materi tertentu, dimana disaat guru menjelaskan itu guru juga melihat keseriusan peserta didik saat menyimak penjelasan guru, respon peserta didik saat kegiatan pembelajaran, dan juga kesiapan dalam menjawab pertanyaan dari guru sewaktuwaktu guru bertanya, setelah itu guru juga memberikan tugas untuk dikerjakan. Kemudian untuk kegiatan penutup guru memberikan kesimpulan dari materi yang diajarkan, lalu memberikan arahan untuk pengumpulan tugas dan batasan waktunya. Untuk setiap pertemuan kadang guru memberikan tugas yang bersangkutan dengan materi dengan alokasi waktu hingga jam lima sore hari itu juga dari situ guru melihat apakah ada tanggung jawab peserta didik dalam mengerjakan tugas. Sedangkan untuk merekap tugas dan melihat kebenaran dari tugas yang mereka kerjakan guru merekap tugas tersebut seminggu sekali yaitu jatuh pada hari senin untuk waktuya itu diluar jam pelajaran, dan untuk pengembalian buku dilakukan pada hari kamisnya, dari sini guru juga dapat melihat sikap tanggung jawab yang dimiliki peserta didik dalam kegiatan pembelajaran secara daring/ online. Kendala dalam kegiatan pembelajaran daring yaitu pertama masalah sinyal/ jaringan, kedua kurangnnya fokus pada peserta didik dan yang ketiga handphone yang kurang memadai.

Peserta didik yang terlambat dalam kegiatan pembelajaran tidak langsung bergabung kedalam pelaksanaan zoom, tetapi mereka akan konfirmasi terlebih dahulu kepada guru karena dari awal ajaran mereka sudah membuat kesepakatan mengenai proses pembelajaran. Yang terakhir guru memiliki catatan penilaian sikap terutama mengenai sikap tanggung jawab peserta didik dalam setiap langkah atau pada proses dari mulai sampai berakhir pembelajaran.

Hasil penelitian sebelumnya yang dilakukan oleh Sari Fatul Mutmainah dengan judul implementasi pembelajaran daring dalam membentuk karakter tanggung jawab. Hasil penelitian menggambarkan sekolah telah melaksanakan penerapakan pembelajaran secara daring secara keseluruhan yang dapat membentuk adanya karakter tanggung jawab, seperti siswa mengikuti kegiatan pembelajaran melalui WA grub, mengumpulkan tugas tepat waktu setiap hari sabtu, visi dan misi, dan tujuan sekolah serta semua kegiatan yang ada dipembelajaran secara daring dilaksanakan semua wali kelas dan guru-guru yang berada di SD Negeri 34/1 Teratai 3.Mengevaluasi pembelajaran daring dalam 
mengembangkan karakter tanggung jawab berdasarkan hasil wawancara dan observasi maka sub masalah ketiga dalam penelitian ini dapat terjawab yaitu mengevaluasi pembelajaran daring pada mata pelajaran ekonomi di SMA Kemala Bhayangkari $1 \mathrm{Kubu}$ Raya.

Untuk mengevaluasi kegiatan pembelajaran pada masa sekarang ini guru melakukan dengan tiga cara, pertama dari kehaidran peserta didik, kedua kesiapan dalam pembelajaran, ketiga pengumpulan tugas peserta didik. Cara pertama untuk mengevaluasi adalah dengan melihat kehadiran peserta didik, dimana kegiatan mengabsen dilakukan dengan menggunakan aplikasi whats app dan dengan cara merespon pesan yang dibagikan dalam gurp kelas tersebut dengan batasan waktu yang telah disepakati. Peserta didik yang terlambat dalam mengabsen tidak boleh langsung masuk kedalam zoom mereka perlu menghubungi guru mata pelajaran dan menunggu keputusan dari guru apakah boleh mengikuti pelajaran atau tidak. Kedua dengan melihat kesiapan dari peserta didik dalam proses pembelajaran berlangsung yang terjadi secara daring dengan aplikasi zoom meeting. Yang dilihat guru adalah sikap yang baik sebagai seorang pelajar jika guru mengucapkan salam maka peserta didik harus menjawab salam, kemudian kesiapan menerima materi yang akan di sampaikan oleh guru, jika pada proses pembelajaran berlangsung apakah peserta didik mengikuti sampai akhir, kesiapan dalam berpakaian, posisi pada saat kegiatan zoom berlangsung dan juga melihat kelengkapan alat tulis. Cara ketiga yaitu dengan pengumpulan tugas. Guru menggunakan dua cara untuk mengumpulkan tugastugas peserta didik, pertama melalui aplikasi dan pengumpulan tugas secara langsung yang di kumpulkan setiap hari senin di luar jam pelajar dan dapat diambil kembali pada hari kamis.

Mengevaluasi kegiatan pembelajaran sangat penting dilakukan agar dapat dilihat hasil dari pembelajaran dengan tujuan mengukur tingkat keberhasilan.

Hasil penelitian sebelumnya yang dilakukan oleh Dewi Fatimah yang berjudul analisis pelaksanaan pembelajaran daring pada masa pandemi covid-19 di sekolah dasar untuk penilaian dan evaluasi guru menggunakan aplikasi Whatsapp, untuk mengirim kembali tugas peserta didik yang telah dikoreksi. Selain itu guru juga memberikan penilaian tentang kedisiplinan peserta didik dalam mengumpulkan tugas.

\section{SIMPULAN DAN SARAN Simpulan}

Hasil penelitian beserta pembahasan yang telah peneliti lakukan mengenai implementasi pembelajaran daring dalam mengembangkan karakter tanggung jawab peserta didik pada pembelajaran ekonomi di SMAS Kemala Bhayangkari 1 Kubu Raya, adapun kesimpulannya adalah sebagai berikut:

(1) Perencanaan pembelajaran daring yang dilakukan guru ekonomi dalam mengembangkan karakter tanggung jawab peserta didik di SMA Kemala Bhayangkari Kubu Raya telah dilakukan maksimal yang terlihat dari adanya perencanaan pelaksanaan pembelajaran (rpp) yang dibuat oleh guru mata pelajaran ekonomi sebelum melakukan kegiatan pembelajaran secara online.

Perencanaan pelaksanaan pembelajaran (rpp) pembelajaran daring yang dibuat berbeda dengan rpp pembelajaran secara tatap muka.

Dari rpp tersebut guru mencantumkan aktifitas yang akan terjadi pada saat pembelajaran berlangsung, dari mulai kegiatan mengabsen, memberikan penjelasan materi, penugasan yang akan diberikan serta cara dan waktu dalam mengumpulkan tugas. Dari perencanaan yang dilakukan, guru dapat melihat tanggung jawab peserta didik pada saat pembelajaran berlangsung secara online (daring).

(2) Pelaksanaan pembelajaran daring yang dilakukan guru ekonomi dalam mengembangkan karakter tanggung jawab peserta didik di SMA Kemala Bhayangkari 1 Kubu Raya telah dilakukan maksimal yang terlihat dari pelaksanaan kegiatan pembelajaran yang terjadi dari mulai pembukaan serta cara guru mengabsen peserta didik guru meminta peserta didik merespon chat yang dikirm dengan pesan suara.

Kegiatan inti guru mengingatkan kembali pembelajaran yang lalu, setelah itu guru menjelaskan materi yang akan disampaiakan. Materi yang disampaikan itu sudah dikirim melalui whats app grup, guru meminta peserta didik memasuki aplikasi zoom dan bergabung dengan kode yang telah diberikan, guru menggunakan aplikasi tersebut untuk menjelaskan materi dan melakukan tanya jawab kepada peserta 
didik, kemudian guru penggunaan handphone untuk kegiatan pembelajaran.

aloksi waktu yang ditentukan. Kegiatan penutup guru memberikan kesimpulan dan menutup kegiatan pembelajaran. Dari pelaksanaan pembelajaran yang terjadi secara online (daring) guru dapat melihat tanggung jawab peserta didik.

(3)Evaluasi pembelajaran daring yang dilakukan guru ekonomi dalam mengembangkan karakter tanggung jawab peserta didik di SMA Kemala Bhayangkari 1 Kubu Raya telah dilakukan maksimal yang terlihat dari pertama adalah daftar hadir peserta didik, kedua dilihat dari kesiapan pada proses pembelajaran memberitahukan cara pengumpulan tugas dan berlangsung dan ketiga dengan meihat tugas yang dikerjakan dan dikumpulkan.

\section{Saran}

Dengan melihat hasil implementasi pembelajaran daring dalam mengembangkan karier tanggung jawab peserta didik pada pembelajaran ekonomi di SMA S Kemala Bhayangkari 1 Kubu Raya yang peneliti dapatkan dalam penelitian, sehingga peneliti menyarankan: (1)bagi guru setidaknya lebih memperdalam teknologi yang berkembang, misalnya memperdalam cara membuat video yang semakin menarik perhatian peserta didik, khususnya yang dapat digunakan untuk kegiatan pembelajaran, apabila pandemi belum berakhir peserta didik tetap akan semangat mengikuti kegiatan pembelajaran karena menyenangkan. (2)bagi peserta didik sebaiknya mengembangkan tanggung jawab terhadap pembelajaran dan lebih mementingkan dan mendahulukan penggunaan handphone untuk kegiatan pembelajaran.

\section{DAFTAR RUJUKAN}

Asriati, N., Alfandi., Priyadi, A.T., Sabri, T., Samudra, Y.T.J., \& Rezeki, Y.S. (2019). Pedoman Penulisan Karya Ilmiah: skprisi. Tesis, Artikel, Hasil Penelitian. ( cetaka ke I, edisi kesimbilan; revisi). Pontianak FKIP UNTAN.

Al-Tabany, B. I. T. (2014). Mendesain Model Pembelajaran Inovatif, Progresif, dan Kontekstual. Jakarta: PT. Kharisma Putra Utama.

Hamdani. (2011). Strategi Belajar Mengajar. Bandung: Cv. Pustaka Setia.

Hariyanto, Samani. M. (2014). Pendidikan

Karakter. Bandung: Pt. Remaja Rosdakarya.

Komalasari, K. (2017). Pendidikan Karakter

Konsep dan Aplikasi Living Values

Education. Bandung: PT. Refika Aditama. Lickona

Thomas. (2013). Mendidik Untuk Membentuk

Karakter. Jakarta: Bumi

Aksara

Majid Abdul. (2014). Strategi Pembelajaran. Bandung: Pt. Remaja Rosdakarya.

Mustari Mohamad. (2017). Nilai Karakter Refleksi Untuk Pendidikan. Depok: Pt. Rajagrafindo Persada.

Sugiyono. (2018). Metode Penelitian Kombinasi (Mixed Methods). Bandung: Alfabeta.

Suprijono Agus. (2014). Cooperative Learning Teori dan Aplikasi Paikem.Yogyakarta: Pustaka Belajar.

Zubaedi. (2015). Desain Pendidikan Karakter. Jakarta: Prenadamedia Group.

Zuriah Nurul. (2011). Pedidikan Moral dan Budi Pekerti Dalam Perspektif Perubahan. Jakarta: PT. Bumi Aksara. 